\title{
IMPACT OF CERTAIN CIVIL LITIGATION ON THE STATUTE OF LIMITATIONS FOR CONTRACTUAL CLAIMS
}

\author{
Natia Makhatadze, \\ Associate Professor,
}

Georgian National University SEU

\begin{abstract}
The concept of statute of limitations in the material sense is closely related to procedural law. Restoration of a violated right of a person is carried out by filing a lawsuit in court. That is why it is crucial to analyze the issue of the impact of the statute of limitations on individual civil litigation.

The article is devoted to the study of the issue of the impact of certain procedural actions, including the suitability of the party, the rejection of the claim, investigating the issues related to the impact of filing a claim on the statute of limitations. In general, it should be taken into account that the given procedural actions have important legal consequences for the party, although it is essential to consider these procedural actions in terms of statute of limitations, in particular, to assess whether the plaintiff or defendant's involvement in legal action leads to the termination of statute of limitations. In general, it should be noted that the filing of a claim by a proper plaintiff constitutes a means of terminating the statute of limitations on the claim, although the party's inadequate consideration substantially alters the legal status. In addition, the legal consequences of a denial of a claim are not unequivocally identified by law, in particular, it is unclear whether a waiver of a claim is a valid remedy for termination of the statute of limitations. Based on the principle of definiteness, a clear regulation should be established regarding the given issue. However, in the current legislative regulation, no obvious impact of filing a claim is identified before initiating the lawsuit on the statute of limitations.

The article also devotes to the analysis of the peculiarities of making a judgment in absentia in the statute of limitations and the application of the statute of limitations in the court of higher instance.

It should be noted that there is a heterogeneous approach to the named issues, which, given the essence of the statute of limitations, may lead to a violation of the legitimate interest of the person. An in-depth study of the mentioned issues is presented and recommendations are proposed to ensure the identification and uniform explanation of the issues.
\end{abstract}

Keywords: statute of limitations, case proceedings, provision, judgment in absentia, impact, termination, counterclaim.

\section{Introduction}

The concept of statute of limitations was not known in ancient Roman law. Its onset is associated with Praetor's Edicts. The praetors initiated a number of new types of lawsuits. ${ }^{66}$ Statute of limitations involves the term established by law, during which the person whose right has been violated can protect the right in

${ }^{66}$ J. Hasler, „Die Wirkung der Verjährung bei der Schuldklage“, Kessinger Publishing, 1872, 3. 
court. ${ }^{67}$ In addition, the Civil Code of Georgia (hereinafter referred to as the CCG) provides for the possibility of protection of rights in a non-judicial manner. However, the most common way to protect a right is to go to court.

There is a significant connection between substantive and procedural law, since violation of substantive law results in the enforcement of a right. "Limitation in the material sense is closely related to the procedural understanding of the right to sue." 68 That is why it is of practical importance to analyze the impact on the statute of limitations of a separate procedural action, which determines the urgency of the presented issue.

The research presented in the paper is divided into three chapters:

The first chapter is devoted to the analysis of the impact of certain issues related to the proceedings (suitability of the party, refusal to accept the claim, application for securing the claim) on the statute of limitations.

The second chapter discusses the peculiarities of making a decision in absentia in the statute of limitations, on the examples of non-filing of a counterclaim, non-appearance of the defendant.

The third chapter deals with the issue of the application of the statute of limitations in the court of higher instance.

\section{Impact of Certain Issues Related to Legal Proceedings on the Statute of Limitations}

Article 138 of the Civil Code of Georgia stipulates that one of the grounds for termination of the statute of limitations is the filing of a claim by an authorized person or the satisfaction of the claim in another way (application to a state body or court and/or enforcement action).

It should be noted that when terminating the limitation period, a number of procedural-legal aspects should be taken into account, which will be discussed in detail.

1.1. The question of the adequacy of the party in the context of the termination of the statute of limitations

A person who believes that his/her right has been violated has the right to initiate a case in court. ${ }^{69}$ In some cases, the plaintiff may err in the person of the obligor or have a misconception about their right. This factual circumstance can be revealed at the stage of the legal process. The Procedural law does not provide for the existence of an improper party as a ground for dismissing a claim. This occurrence is subject to revision at the next stage of receiving the lawsuit. ${ }^{70}$ This is why the question naturally arises whether the involvement of an improper plaintiff or defendant in the litigation process leads to the termination of the statute of limitations.

\footnotetext{
${ }^{67}$ Judgment of the Chamber of Civil Cases of the Supreme Court of Georgia of November 15, 2011 in the case AS-988-10212011.

${ }^{68}$ A. Kobakhidze, “Civil Law, I, General Part”, Ltd. "Herald of Georgia” Press, Tbilisi, 2004, p. 360.

${ }^{69}$ Law of Georgia "Civil Procedure Code of Georgia", Part 1 of Article 2, Departments of the Parliament of Georgia, №47-48, 31 / 12.1997, Registration Code: 060.000.000.05.001.000.301.

${ }^{70}$ Sh. Kurdadze, N. Khunashvili, "Georgian Civil Procedure Law”, Second Edition, "Meridiani” Publishing House, Tbilisi, 2015, p. 163.
} 
At the initial stage of the case, the court is not aware of the suitability of the plaintiff or the defendant. ${ }^{71}$ The court has less discretion in changing the wrong party. If the proper plaintiff is identified, the court must replace it. ${ }^{72}$ In general, the relevant party in the process is a person who has a material-legal interest in a particular case. ${ }^{73}$ A person's child or spouse may not be allowed to speak in the proceedings. The change of the improper party in the proceedings should be considered as a change of claim. Accordingly, the defendant should be able to indicate the statute of limitations when the claim is statute-barred at the time the claim is served on it. ${ }^{74}$ The idea that a claim brought by an improper plaintiff or an improper defendant should not lead to the expiry of the statute of limitations must be fully shared ${ }^{75}$ since the termination of the claim is caused only by a suit filed by an authorized person. ${ }^{76}$ In discussing the statute of limitations in one of the cases, the Supreme Court rightly stated that it could not assess the issue of statute of limitations on the claim because the claim had not been brought against the proper defendant. ${ }^{77}$

However, a different opinion is expressed. In particular, erroneous reference to a party in a lawsuit should lead to the termination of the statute of limitations only when it is possible to identify the creditor or the debtor through an explanation. ${ }^{78} \mathrm{~A}$ similar solution to the issue can be associated with insurmountable complexity as it is difficult to identify the appropriate creditor or debtor at an early stage of the litigation process. However, the issue of the subject obliged to explain is also vague.

The research of the issue should be carried out in close connection with the consequences of the expiration of the statute of limitations. It should be noted that the delay of the statute of limitations leads to the rejection of the claim by the creditor. ${ }^{79}$ However, the court will consider the issue of limitation only if it is disputed by the party. ${ }^{80}$ Accordingly, the statute of limitations has no effect without reference to the party ${ }^{81}$

In considering this issue, the above-mentioned circumstance should be considered as essential. Since the examination of the statute of limitations by the court is done only with the reference of the party, it is necessary that this reference be made by an authorized person. The will of the proper and improper parties may not be consistent. Taking into account the will of the improper plaintiff or defendant would be incompatible with the requirement of stability of civil turnover as well as equal protection of the interests of the parties. The will expressed by an unauthorized person cannot replace the will of the appropriate party, and each participant in the process bears the risk that the wrong data will be reflected by them in the lawsuit. Accordingly, in assessing the issue of statute of limitations, only the will expressed by the appropriate party should be taken into account. However, since the proper replacement of the improper plaintiff is carried out

${ }^{71}$ T. Liluashvili, G. Liluashvili, V. Khrustali, Z. Dzlierishvili, Civil Procedure Law, Part I, "Samartali” Publishing House Tbilisi, 2014, p. 144.

72 Judgment of the Chamber of Civil Cases of the Supreme Court of Georgia of 11 July 2007 in the case AS-322-675-07.

${ }^{73}$ Kurdadze, Khunashvili. See footnote 5, p. 162

${ }^{74}$ R. Burbulla, Parteiberichtigung, Parteiwechsel und Verjährung, Monatsschrift für Deutsches Recht, 61. Jahrgang, Heft 8, 2007, 445

${ }^{75}$ G. Amiranashvili, The Impact of an Authorized Person's Appeal on the Limitation of Complaints, Student Law Journal, European Law Students Association, 2013, p. 66; A. Koller, Entry Brechung der Verjährung, Swiss Jurisprudence 113 (2017) Nr. 9, 2017, 201.

${ }^{76}$ Co-authors: Editor L. Chanturia, "Commentary on the Civil Code of Georgia", Book I, "Samartali", Publishing House Tbilisi, 1999, p. 332

${ }^{77}$ Judgment of the Chamber of Civil Cases of the Supreme Court of Georgia of November 7, 2011 in the case AS-352-335-2011.

${ }^{78}$ Burbulla, 444.

${ }^{79}$ Judgment of the Chamber of Civil Cases of the Supreme Court of Georgia of December 27, 2018 in the case №AS-1428-2018, paragraph 96.

${ }^{80}$ Judgment of the Chamber of Civil Cases of the Supreme Court of Georgia of June 9, 2014 in the case №AC-880-838-2013.

${ }^{81}$ Judgment of the Chamber of Civil Cases of the Supreme Court of Georgia of January 9, 2015 in the case №AS-307-289-2014, Judgment of the Chamber of Civil Cases of the Supreme Court of Georgia of April 17, 2015 in the case №AS-58-57-2014. 
without termination of the proceedings, the relevant moment of termination of the statute of limitations should be considered not the date of filing a lawsuit, but the moment of involvement of the proper plaintiff in the litigation process. This is entirely reasonable in view of the substance of the statute of limitations.

\subsection{Impact of a refusal to accept a claim on the statute of limitations}

Article 140 of the Civil Code of Georgia regulates the legal consequences of rejecting a claim and leaving the claim unconsidered in the context of statute of limitations. In particular, leaving the claim unconsidered does not lead to the termination of the statute of limitations, while the repeated submission of the claim by the authorized person leads to the termination of the statute of limitations from the date of filing the first claim.

In some cases, the claim may meet the formal requirements established by law, therefore, be registered by the Chancellery of the Court, but the judge may reject the claim on any of the grounds provided for in Article 186 of the Civil Procedure Code of Georgia (hereinafter referred to as the CPCG). According to the literal explanation of Article 140 of the Civil Code, it applies only in cases of rejection of the claim by the plaintiff and leaving the claim unconsidered. Consequently, since this list does not include the rejection of a claim, it is possible that this procedural document will lead to different legal consequences in terms of statute of limitations. In one of the litigation cases, the parties argued with reference to this argument that the rejection of the claim is another procedural document and should not fall within the scope of Article 140 of the Civil Code. ${ }^{82}$

The court made a significant explanation regarding the issue under consideration. In particular, the grounds for termination of the statute of limitations are only the application or claim of the person that has been accepted by the court, ${ }^{83}$ and if the authorized person refuses to accept the application or claim in the proceedings, the statute of limitations will not be terminated. ${ }^{84}$

A similar approach is laid down in Austrian law. In particular, the termination of the statute of limitations on the filing of a claim is based on the existence of several preconditions: reaching the claim in court, continuing the proceedings properly or making a decision desirable for the plaintiff. ${ }^{85}$ Accordingly, the ground for termination is valid only if the court continues the litigation process and makes a final decision. ${ }^{86}$

In the study of this issue, the title of Article 140 of the Civil Code itself should be taken into account, which generally addresses the rejection of the lawsuit. This includes all cases when the case is not considered on the merits. Accordingly, Article 140 of the Civil Code must be interpreted in terms of its purpose and not the literal meaning of the terms used. ${ }^{87}$ At the same time, the legal consequences of revealing the grounds for refusal to accept the claim in the court process are also noteworthy. Pursuant to Articles 272 and 275 of the CPCG, this leads to either the termination of the proceedings or the dismissal of the claim. Accordingly,

\footnotetext{
82 Judgment of the Chamber of Civil Cases of the Supreme Court of Georgia of 23 July 2015 in the case №AS-646-612-2015, paragraph 24.

${ }^{83}$ Judgment of the Chamber of Civil Cases of the Tbilisi Court of Appeals of 2 December 2014 in Case №2B/2737-14.

${ }^{84}$ Judgment of the Chamber of Civil Cases of the Supreme Court of Georgia of 19 November 2007 in the case №AS-271-601-07; Judgment of the Chamber of Civil Cases of the Supreme Court of Georgia of January 26, 2016 in the case №AS-493-467-2015, paragraph 27.

${ }^{85}$ F. Gschnitzer, „Allgemeiner Teil des bürgerlichen Rechts “, Springer-Verlag, Wien, 1966, 251.

${ }^{86}$ Ibid.

87 Judgment of the Chamber of Civil Cases of the Supreme Court of Georgia of 22 April 2013 in the case №AS-1586-1489-2012.
} 
in the interests of the parties, such an interim act should not lead to the termination of the statute of limitations. However, in order to avoid any misunderstanding, it is advisable to indicate the case of refusal to accept the claim in Article 140 of the Civil Code.

However, in order to enforce the essence of the institute of statute of limitations and the will of the legislator, it is advisable not to limit the scope of Article 140 of the Civil Code to procedural documents issued by the court and to apply to acts adopted by other bodies, and the party has the opportunity to apply to the court in accordance with the general rule. For example, the rule established by Article 140 of the Civil Code may be applied to claims for payment of debts under Chapter XVI1 of the Law of Georgia on Enforcement Proceedings, when the Chairman of the National Bureau of Enforcement refuses to issue a debt repayment order. In this case, the party may, as a general rule, bring an action against the applicant. ${ }^{88}$

\subsection{The effect of securing the lawsuit on the statute of limitations}

Compiling a lawsuit requires finding certain documents, translating them, establishing a legal position. When the risk of infringement is imminent, it is possible to file a lawsuit for securing the lawsuit without the above-mentioned procedures. It is not necessary to formulate a clear legal position when applying to the court with a suit for securing a suit, it is enough to justify that without applying a measure to secure a claim, there will be a threat to the execution of the decision, otherwise to the violated right. ${ }^{89}$

Whether a statement of security for a claim filed before a lawsuit is a valid remedy for termination of the statute of limitations has already been the subject of a court hearing in one of the cases. Therefore, it is essential to discuss the main motivations.

Pursuant to Article 138 of the Civil Code, the statute of limitations is terminated if the authorized person files a claim to satisfy or determine the claim, or tries to satisfy the claim by other means, such as appealing to a state body or court, or taking enforcement action.

According to the court, the claim for securing a claim cannot be considered as a claim under the specified norm, as the claim must be directed to satisfy the claim or it must be made in defense of the substantive right or its establishment. Accordingly, in the event of such a statement, the court must have the opportunity to discuss and substantively resolve the dispute. ${ }^{90}$ The statement on securing the claim does not serve to establish or protect the right, but its purpose is to create such preconditions for the plaintiff that in case of satisfaction of the claim, they can carry out the effective execution of the court decision without any obstacles, i.e. exercising the already established right. ${ }^{91}$

The court uses the security of the claim only if the plaintiff proves that the main claim that is being secured is substantiated and there is a reasonable probability of satisfying the claim. ${ }^{92}$

A different approach to this issue is established by German law. Paragraph 204 of the German Civil Code provides for the suspension of statute of limitations even if the claim is not for the exercise of a right but

\footnotetext{
${ }^{88}$ Law of Georgia on Enforcement Proceedings, Article 917, Paragraph 9, Legislative Herald of Georgia, №13 (20), 01/05/1999.

${ }^{89}$ Law of Georgia "Civil Procedure Code of Georgia", the first part of Article 191, Departments of Parliament, №47-48, $31 /$ 12.1997, registration code: 060.000.000.05.001.000.301.

${ }^{90}$ Judgment of the Chamber of Civil Cases of the Supreme Court of Georgia of 4 April 2011 in the case №AS-71-62-2011.

${ }^{91}$ Judgment of the Chamber of Civil Cases of the Supreme Court of Georgia of 4 April 2011 in the case №AS-71-62-2011.

${ }^{92}$ Explanatory Report on the Draft Law of Georgia on Amendments to the Civil Procedure Code of Georgia, №07-3 / 597/8,

$<$ https://info.parliament.ge/file/1/BillReviewContent/123544?> [L. s. 24.03.2021].
} 
for the provision of legal aid for the proceedings. ${ }^{93}$ The suspension of the statute of limitations shall be accompanied by a complete and, accordingly, substantiated statement submitted to the court before the expiry of the time limit. ${ }^{94}$ The suspension of the statute of limitations is triggered by an application to the court for the provision of evidence. ${ }^{95}$ In this case, the principle applies that the debtor no longer needs protection when the creditor has expressed a clear will to enforce the claim by using measures related to the proceedings. ${ }^{96}$

When filing a claim for security before filing a claim, a party reveals a clear will to pursue the claim later. Therefore, it should not be considered appropriate to restrict the claim for security purposes. The goal of the party, to finally enforce the decision, will become unrealizable in the statute of limitations. Accordingly, in the first place, the plaintiff's purpose is to protect the statute of limitations and then to achieve other purposes. However, since a claim for securing a claim also includes the submission of information on the material merits of the claim, it is advisable to file an application with a reasoned claim for securing the statute of limitations, which excludes the possibility of termination of the statute of limitations when filing an unsubstantiated claim. When considering the application, the judge at least partially discusses the material merits of the claim not only on the basis of the assumptions but also on the basis of the submitted documents. $^{97}$

However, taking into account the peculiarities of the institute of securing the claim before initiating the lawsuit, when considering the issue of protection of the statute of limitations, it is advisable for the court to take into account the issue of filing the lawsuit within 10 days. The fact that the plaintiff does not file a subsequent claim negates the apparent will of the party to enforce the claim and increases the risk of abuse of the right by the latter. Accordingly, it is advisable to secure the claim before initiating the claim as a basis for termination of the statute of limitations only in the presence of the fact of subsequent filing of the claim.

\section{Peculiarities of Making a Decision in Absentia in the Statute of Limitations}

Chapter XXVI of the CCG regulates issues related to making decisions in absentia. Articles 229-230 of the CCG provide for two grounds for a default judgment: the failure of the party to appear or the defendant to file a counterclaim. Judgment in absentia is limited to the discretion of the judge. The claim will be satisfied only if the circumstance indicated in the claim legally justifies the claim. Otherwise, the judge will dismiss the claim. ${ }^{98}$

When making a decision in absentia, it is important to consider the issue of statute of limitations. The question is whether the court can refuse to satisfy the claim in the absence of grounds for a decision in absentia, taking into account the issue of statute of limitations. Since the grounds for making an absentee decision are different, each ground requires an individual assessment.

\footnotetext{
${ }^{93}$ F. Peters, Der Antrag auf Gewährung von Prozesskostenhilfe und die Hemmung der Verjährung, JR Heft 4/2004, $2004,137$. ${ }^{94}$ BGH Urt. v. 22/03/2001 - IX ZR 407/98.

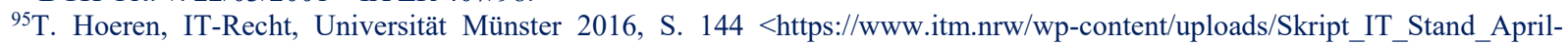
2017.pdf> [L. s. 24.03.2021].

${ }^{96}$ M. Philipp, „Verjährungshemmung durch Rechtsverfolgung, Insbesondere ein Beitrag zur Behandlung verfahrensrechtlich fehlerhafter Rechtsverfolgungsmaßnahmen des §204 Abs. 1 BGB“, „Mohr Siebeck“, Tübingen 2018, 90.

${ }^{97}$ Law of Georgia on "Civil Procedure Code of Georgia", the first part of Article 191, Departments of Parliament, №47-48, 31 / 12.1997, registration code: 060.000.000.05.001.000.301.

${ }^{98}$ Law of Georgia on "Civil Procedure Code of Georgia”, Part 2 of Article 230, Departments of Parliament, №47-48, 31 /

12.1997, registration code: 060.000.000.05.001.000.301.
} 


\subsection{Failure to file a counterclaim as a ground for making decision in absentia}

The CCG is based on the principle of disposition of the parties. The principle of disposition, which is an obvious attempt to implement the private autonomy of the parties in the process, implies the ability of the parties to dispose of substantive and procedural rights. ${ }^{99}$ The principle of disposition implies the freedom of a person to enjoy or refuse to exercise this right. Exercising the right is not an obligation. ${ }^{100}$ The principle of disposition has its limits. In particular, what a party does not have the right to do beyond the proceedings cannot be granted a similar right in the proceedings. ${ }^{101}$

In addition to the principle of disposition, civil proceedings are conducted on the principle of adversarial proceedings, which implies an obligation on the part of the parties to submit the evidence necessary to substantiate their claims. ${ }^{102}$

The principle of adversarial rule excludes the involvement of the court in the process of obtaining evidence. It is up to the autonomy of the will of the parties to appeal to the court. The court is bound by the facts and evidence presented by the party. ${ }^{103}$ The role of the court in this process is passive.

In the proceedings, the jurisdiction of the court is largely limited by four main possibilities: the presentation of additional evidence; ${ }^{104}$ By requesting evidence; On-site inspection and examination. ${ }^{105}$ The action of the court should not restrict the right of the parties to use the procedural form of defense. However, the actions of the court itself cannot be directed against the will of the parties. ${ }^{106}$

The specificity of the statute of limitations lies in the fact that after the expiration of the term established by law, the claim exists objectively and is not terminated; although, its realization depends on the desire of the defendant. ${ }^{107}$ Demand remains as the so-called natural commitment. This is due to the regulation established by the Civil Code, according to which, in case of fulfillment of an older claim, it is not subject to return, according to the norms regulating unjust enrichment. ${ }^{108}$

The right to refuse to fulfill the obligation is the opposite of the obligated person. Therefore, it is necessary for this person to exercise this right. ${ }^{109}$ A person can exercise his material-legal right as he/she wishes, to tolerate or not to tolerate the violation of the right. ${ }^{110}$ The court cannot examine the statute of limitations on its own initiative. ${ }^{111}$ However, there are objections that the court must consider on its own initiative, such as opposition to the prohibitions of the transaction, lack of form, limited legal capacity or the need for

\footnotetext{
${ }^{99}$ Liluashvili, Liluashvili, Khrustali, Dzlierishvili, see. Footnote 6, p. 77.

${ }^{100}$ Ibid., P. 80

${ }^{101}$ Ibid., P. 85.

${ }^{102}$ K. Kvinikadze, Reduction of Penalty for Breach of Contract by the Court as a "Judicial Intervention" on the Principle of Contractual Freedom, Journal of Justice and Law №2 (50) '16, Tbilisi, 2016, p. 89.

${ }^{103}$ Kurdadze, Khunashvili, see. Footnote 5, p. 100.

${ }^{104}$ Law of Georgia “Civil Procedure Code of Georgia”, Article 103, Departments of Parliament, №47-48, 31 / 12.1997, registration code: 060.000.000.05.001.000.301.

${ }^{105}$ Kvinikadze, see footnote 37, p. 88.

${ }^{106}$ I. Merebashvili, Application of the Principles of Adversarial Proceedings and Cctivity of Judges During Civil Cases in Court, Journal of Justice and Law №4 (23) ’09, Tbilisi, 2009, p. 25.

${ }^{107}$ Judgment of the Chamber of Civil Cases of the Supreme Court of Georgia of June 9, 2014 in the case №as-880-838-2013.

${ }^{108}$ R. Bussert, „Bürgerliches Recht für Betriebswirte“, 2. Aufl., Gabler Verlag, Wiesbaden, 2012, S. 114.

109 H. Schäfer, B. Fuhrmann, Zivilrechtliche und rechtsökonomische Aspekte zum Dieselskandal der Volkswagen AG, Wirtschaftsdienst, 98 Jahrgang, Heft 4, (243-251), Heidelberg, 2018, S. 243.

${ }^{110}$ Liluashvili, Liluashvili, Khrustali, Dzlierishvili, see. Footnote 6, p. 81.

${ }^{111}$ L. Chanturia, General Part of Civil Law, Samartali Publishing House Tbilisi, 2011, p. 128.
} 
support. ${ }^{112}$ Limitation is a type of objection which cannot be taken into account without reference to the party. ${ }^{113}$ After the reference to the statute of limitations by the party, it is within the competence of the court to determine whether the statute of limitations was suspended. ${ }^{114}$

A similar regulation is established by the English legal system. In particular, the 1980 Limitation Act is a means and not a right and it has no effect unless declared by a party. ${ }^{115}$ However, the 1980 statute of limitations is a legal objection that a party can rely on. A party is not obliged to use the said objection, however, as a rule, it has the said right. ${ }^{116}$

The reference to the statute of limitations by the court can rightly be considered a violation ${ }^{117}$ of the principle of adversarial proceedings, since the will of the party is not considered in this process. The will of the party is crucial to the final resolution of the issue. The non-use of the counterclaim by the party in the proceedings leads to the satisfaction of the claim. Therefore, it is up to the individual to decide whether to take advantage of such an objection. If the result of the statute of limitations automatically results in the termination of the claim, this may lead to a violation of the dignity of an honest citizen. ${ }^{118}$ That is why the explicit will of the party is necessary for the legal result of the expiration of the statute of limitations. ${ }^{119}$

It follows from the adversarial principle that if a party is given the opportunity to defend a violated right in court, the other party has the right to defend its own interests, including to bring any legal remedies to challenge the defendant's position. In order to challenge the position and to intervene in this process by referring to the statute of limitations, the interests of the plaintiff would clearly be violated. ${ }^{120}$

It is advisable that the submission of a counterclaim by the defendant in the statute of limitations does not cause delays in the execution of the claim, refuse to satisfy the claim on this basis and make a decision in absentia against the debtor even when the claim is statute-barred. ${ }^{121}$

Based on the principle of adversarial proceedings, the prohibition of the statute of limitations to be taken into account by a judge is completely reasonable and in line with the interests of the party and the essence of the statute of limitations. The party may, regardless of the statute of limitations, wish to fulfill the obligation. Accordingly, the will of the party must be decisive in refusing to satisfy the claim on the grounds of limitation.

\subsection{Absence of the defendant as a precondition for making a decision in absentia}

Article 230 of the CCG provides for an absentee decision also in the event that the defendant has not appeared at the hearing and the statute of limitations has expired. ${ }^{122}$ In the absence of the defendant, the

\footnotetext{
112 H. Boeling, L. Chanturia, "Methodology of Decision-Making in Civil Cases", 2nd Edition, Tbilisi, 2003, p. 170-171.

${ }^{113}$ S. Dullinger, „Bürgerliches Recht Schuldrecht Allgemeiner Teil“, Band II, 4. Aufl., SpringerWienNewYork, 2010, Rn. 1/35.

${ }^{114}$ Recommendations of the Supreme Court of Georgia on Problematic Issues of Civil Law Case Law, Tbilisi, 2007, p. 63.

${ }^{115}$ Ronex Properties vs John Laing Construction [1983] QB 393, 404.

116 Oxford Architects Partnership vs Cheltenham Ladies Gollege [2006] APP.L.R 11/17, 15.

117 T. Liluashvili, Civil Procedural Law, 2nd Edition, Law Publishing House, Tbilisi, 2005, p. 62.

${ }^{118}$ L. Rudkowski, „Wirtschaftsrecht: BGB AT, Schuldrecht, Sachenrecht““, „Springer Gabler“, Wiesbaden, 2016, 43.

${ }^{119}$ Ibid.

120 Judgment of the Chamber of Civil Cases of the Supreme Court of Georgia of March 25, 2013 in the case №1350-1275-2012.

${ }^{121}$ Mitgliedern des Bundesgerichtshofes, „Das Bürgerliche Gesetzbuch: mit besonderer Berücksichtigung der Rechtsprechung des Reichtsgerichts und des Bundesgerichtshofs“, §222, Band I, 12. Aufl., 1982, Rn. 1.

${ }^{122}$ Boelling, Chanturia, cf. Footnote 47, p. 172.
} 
circumstances indicated in the claim and not in the explanation of the plaintiff are considered approved. ${ }^{123}$ In the absence of a decision, the circumstances of the case cannot be investigated on the grounds that the party did not appear. Accordingly, when the defendant does not appear at the hearing and does not indicate the circumstances necessary for the statute of limitations on the claim, his/her protest will not be accepted at the stage of the absentee decision on the statute of limitations. ${ }^{124}$ In the absence of the defendant, the decision in absentia to satisfy the claim is doubtful when the defendant in the counterclaim indicated the statute of limitations on the claim.

An argument inadmissible in favor of a judgment rendered in absentia cannot be considered inadmissible by a judge. The reference to the statute of limitations by the defendant in the counterclaim is a sufficient condition for considering the matter, since the party has expressed their will. Statute of limitations is a means and not a right. ${ }^{125}$ In such a case, when the respondent indicated in the objection about the statute of limitations, the claim should not be satisfied. This cannot be justified by any convincing argument. The argument that after a specified period of time the creditor's actual and probable interest is no longer worthy of protection because he/she expressed his/her negligence ${ }^{126}$ determined by his/her inaction does not serve to justify the contingency of the statute of limitations as it would result in a high intensity infringement of the defendant's interests. Accordingly, in the event that a party has indicated in the counterclaim that the claim is time-barred, its non-appearance should not be an unconditional precondition for satisfying the claim, as the judge has the right to assess the circumstances of the counterclaim and to dismiss the claim. However, in such a decision, the issue of the statute of limitations should be indisputable and requires only a legal examination.

\section{Peculiarities of the Use of the Statute of Limitations in the Court of Higher Instance}

One way to protect oneself from a lawsuit is to refer to the statute of limitations. However, is it permissible to file a statute of limitations at any time?

When discussing the counterclaim as a means of defense, it is important to mention its legal nature. In order to prove the purely procedural nature of filing a counterclaim, the will of the legislator may be cited, which, in contrast to the substantive and procedural counterclaims, indicates that a counterclaim may be conducted only in the process and directed against the enforcement of the claim. ${ }^{127}$ However, from a procedural point of view, the two stages must be distinguished from each other. Filing a counterclaim leads to a rejection of the claim and thus improves the debtor's condition. ${ }^{128}$ From a material-legal point of view, it can exist only beyond the feasibility of an existing claim, because a non-existent claim does not already exist. ${ }^{129}$ When a party appeals against the statute of limitations, it is not necessary to specify a particular date; it is enough

\footnotetext{
${ }^{123}$ S. Chkhaidze, Absentee Decision in Civil Process - Main Problems, Analysis of Judicial Practice, Journal of Justice and Law №4'12 Tbilisi, 2012, p. 42.

${ }^{124}$ Judgment of the Chamber of Civil Cases of the Supreme Court of Georgia of October 9, 2015 in the case №AS-898-860-2014.

${ }^{125}$ Judgment of the Chamber of Civil Cases of the Supreme Court of Georgia of March 25, 2013 in the case AS-1350-1275-2012

${ }^{126}$ M. Schmidt-Kessel, „Ein einheitliches europäisches Kaufrecht? Eine Analyse des Vorschlags der Kommision“, „De Gruyter“ München, 2012, 529.

${ }^{127}$ C. Meller-Hannich, Die Einrede der Verjährung, in JuristenZeitung, 60. Jahrgeburtstag, №13, 2005, 664.

${ }^{128}$ M. Klose, Vindikationsverjährung: Gewogen für verfassungswidrig befunden! Rewiss (RW) Heft 2, 2014, 233.

${ }^{129}$ Ibid.
} 
for the debtor to just argue with the creditor that his claim is overdue, which may not be expressed in a specific legal sense as "not demanded to fulfil the commitment for specified amount of time"130

Filing a counterclaim to the statute of limitations is not unrestricted. The reference to the statute of limitations of the representative in one of the cases was not considered by the court as a sufficient basis for assessing the statute of limitations and explained that from a procedural point of view, the statute of limitations is considered by the court only when the party in the case indicates it. As the counterclaim had not been disputed the statute of limitations, the removal of the representative from the proceedings without sufficient evidence does not provide an opportunity to consider the issue of statute of limitations. ${ }^{131}$

The court's reasoning on this issue is vague. The fact that the request in the objection does not indicate the statute of limitations should not deprive the party of the right to file the indicated objection during the substantive hearing of the case if he/she later learns about the mentioned fact. Otherwise, the stages of preparation and substantive consideration of the case will be lost and the judge will be able to make a decision only on the basis of the claim and the counterclaim.

Statute of limitations is considered as a factual circumstance of the case, while the party is limited in referring new facts and evidence to a higher instance. The issue of statute of limitations can be raised only in the court of first instance and partly in the court of appeal, while it is inadmissible in the court of cassation. ${ }^{132}$ In the Court of Appeals, the parties have the right to submit any evidence, the admissibility of which is examined by the court in accordance with the rules established by the procedural law. ${ }^{133}$

Submission of new facts and evidence to the Court of Appeals is allowed only in cases precisely defined by law. However, the Court of Appeals must consider several circumstances. In particular, if the facts have arisen after the hearing of the case in the court of first instance, it must be admitted. In addition, the Court of Appeals would examine whether a party could present these factual circumstances and evidence in a court of first instance. ${ }^{134}$

Objection to the statute of limitations is admissible in the appellate instance if the court's assessment of the nature of the legal relationship between the parties differs from the plaintiff's assessment and the defendant has no opportunity to defend his/her interests given the objective circumstances. ${ }^{135}$ The court of cassation cannot refer ${ }^{136}$ to the statute of limitations of the claim, as it evaluates the decision of the Court of Appeals only in terms of legality. This is undoubtedly a logical solution to the issue.

The approach of German law to this issue differs slightly, in particular, the defendant can indicate the statute of limitations on the claim no later than the last instance hearing of the factual circumstances. The defendant no longer has the right to refer to statute of limitations in the Court of Cassation. ${ }^{137}$ It is clear from the above-mentioned regulation that reference to the statute of limitations is permissible in the courts of first and appellate instance, while reference to the mentioned in the cassation instance is excluded. In addition, paragraph 531 II of the German Code of Civil Procedure sets out the preconditions for the admissibility of

\footnotetext{
130 Judgment of the Chamber of Civil Cases of the Supreme Court of Georgia of February 17, 2017 in the case №AS-1063-10232016; Chanturia, see. Footnote 46, p. 128.

${ }^{131}$ Judgment of the Chamber of Civil Cases of the Supreme Court of Georgia of January 12, 2012 in the case №AS-1509-15172011.

${ }^{132}$ Important Definitions of the Supreme Court of Georgia, Tbilisi, 2016, 96.

${ }^{133}$ Sh. Kurdadze, "Consideration of Civil Cases in Superior Courts", Meridiani Publishing House, Tbilisi, 2006, p. 25

${ }^{134}$ Liluashvili, see Footnote 52, p. 348-349.

${ }^{135}$ Important Explanations of the Supreme Court of Georgia, Tbilisi, 2016, p. 96.

136 Judgment of the Chamber of Civil Cases of the Supreme Court of Georgia of 25 March 2013 in the case №-1350-1275-2012.

${ }^{137}$ Members of the Bundesgerichtshofes, see Footnote 56, Rn. 1.
} 
a defense in the Court of Appeal. In particular, it is permissible if the submission in the first instance is not caused by the negligence of the party.

The submission of a statute of limitations by the party to the district/city court at all stages should be considered a reasonable solution to the issue, and to a limited extent in the appellate court, as procedural law imposes restrictions on new facts and evidence before the appellate court. However, if due to objective circumstances it was impossible for the person to refer to the statute of limitations in the district/city court, this should be allowed during the hearing of the case in the appellate instance, which examines the decision from both factual and legal point of view. As for the Court of Cassation, due to the limited review established by law (only the review of legality), the reference to the statute of limitations in the Court of Cassation should be named as an objective impossibility.

\section{Conclusion}

Theses and propositions identified as a result of working on the paper can be formulated in the form of the following concluding propositions:

1. The law does not define the legal consequences of involving an improper plaintiff or improper defendant in the litigation process in terms of statute of limitations. It is advisable that the will of the improper plaintiff or defendant does not affect the flow of the statute of limitations. In general, the will expressed by an unauthorized person cannot replace the will of the appropriate party and each participant in the process bears the risk that will result from the reflection of erroneous data by them in the lawsuit. Therefore, in assessing the issue of statute of limitations, only the will expressed by the appropriate party should be taken into account. However, since the improper plaintiff is properly replaced without termination of the proceedings, the relevant moment of termination of the statute of limitations when filing a lawsuit should be considered not the date of filing a lawsuit with the court, but the moment of proper plaintiff involvement in the litigation.

2. According to the verbal explanation of Article 140 of the Civil Code, it applies only in cases of rejection of the claim by the plaintiff and leaving the claim unconsidered. Consequently, since this list does not include the rejection of a claim, it is possible that this procedural document will lead to different legal consequences in terms of statute of limitations. In the study of this issue, the title of Article 140 of the Civil Code itself should be taken into account, which generally addresses the rejection of the lawsuit. This includes all cases when the case is not considered on the merits. Accordingly, Article 140 of the Civil Code must be interpreted considering its purpose and not the literal meaning of the terms used. However, in order to enforce the essence of the institute of statute of limitations and the will of the legislator, it is advisable not to limit the scope of Article 140 of the Civil Code to procedural documents issued by the court and to apply to acts adopted by other bodies by which the dispute is not substantially settled and the party has the opportunity to appeal to the court in accordance with the general rule.

3. The legislation leaves open the question of the impact of the statute of limitations before the lawsuit is filed. When filing a claim for security before filing a claim, a party reveals a clear will to pursue the claim later. Accordingly, it should not be considered appropriate to limit the claim for security purposes. It is advisable to file an application with a reasoned statement of securing the claim followed by termination of the statute of limitations. However, taking into account the peculiarities of the institute of securing the claim before initiating the lawsuit, when considering the issue of protection of the statute of limitations, it is 
advisable for the court to take into account the issue of filing the lawsuit within 10 days. The fact that the plaintiff does not file a subsequent claim negates the apparent will of the party to enforce the claim and increases the risk of abuse of the right by the latter. Accordingly, it is advisable to secure the claim before initiating the claim as a basis for termination of the statute of limitations only in the presence of the fact of subsequent filing of the claim.

4. In the absence of the defendant, the decision in absentia to satisfy the claim is doubtful when the defendant in the counterclaim indicated the statute of limitations on the claim. An argument inadmissible in favor of a judgment rendered in absentia cannot be considered inadmissible by a judge. The reference to the statute of limitations by the defendant in the counterclaim is a sufficient condition for deliberation on the matter since the party has expressed their will. Accordingly, in the event that a party has indicated in the counterclaim the claim to be statute-barred, its non-appearance should not be an unconditional precondition for satisfying the claim, as the judge has the right to dismiss the claim if assessed and confirmed in the counterclaim. However, in such a decision, the issue of statute of limitations should be indisputable and requires only a legal review.

5. The law does not specify a specific time for filing a statute of limitations in common courts. It is advisable to allow the filing of a statute of limitations in the district/city court at all stages, but with limited extent in the appellate court, as procedural law imposes restrictions on the review of new facts and evidence in the appellate court. As for the Court of Cassation, the use of the statute of limitations in the Court of Cassation should be named as an objective impossibility due to the limited review established by law (only the review of legality). 


\section{Bibliography:}

1. Law of Georgia on Enforcement Proceedings, Paragraph 9 of Article 917, Legislative Herald of Georgia, №13 (20), 01/05/1999;

2. Law of Georgia on Civil Procedure Code of Georgia, Article 2, Part 1, Article 103, Article 191, Part 1, Article 230, Part 2, Departments of Parliament, №47-48, 31/12.1997, Registration code: 060.000.000.05.001.000.301;

3. Explanatory Card on the Draft Law of Georgia on Amendments to the Civil Procedure Code of Georgia, №07-3/597/8, https://info.parliament.ge/file/1/BillReviewContent/123544? [Last seen 24.03.2021];

4. Giorgi Amiranashvili, "The Impact of an Authorized Person's Appeal on the Limitation of Litigation", Student Law Journal, European Law Students Association, 2013;

5. Collective of authors: Editor Lado Chanturia, "Commentary on the Civil Code of Georgia", Book I, Samartali Publishing House, Tbilisi, 1999;

6. Hein Boelling, Lado Chanturia, "Methodology of Decision-Making in Civil Cases", 2nd Edition, Tbilisi, 2003;

7. Ketevan Kvinikadze, Reduction of Fine by the Court as a "Judicial Intervention" in the Principle of Contractual Freedom, Journal “Justice and Law” №2 (50) '16, Tbilisi, 2016;

8. Avtandil Kobakhidze, "Civil Law, I, General Part", Ltd. "Georgian Herald" Press, Tbilisi, 2004;

9. Tengiz Liluashvili, Gia Liluashvili, Valeri Khrustali, Zurab Dzlierishvili, Civil Procedure Law, Part I, Samartali Publishing House, Tbilisi, 2014;

10. Tengiz Liluashvili, "Civil Procedural Law", 2nd edition, Samartali Publishing House, Tbilisi, 2005;

11. Irma Merebashvili, "Application of the Principles of Adversarial Proceedings and Activity of Judges in Civil Cases During the Court Proceedings”, Journal of Justice and Law №4 (23) '09, Tbilisi, 2009;

12. Recommendations of the Supreme Court of Georgia on problematic issues of civil law case law, Tbilisi, 2007 ;

13. Important Explanations of the Supreme Court of Georgia, Tbilisi, 2016;

14. Shalva Kurdadze, "Hearing of Civil Cases in Higher Courts", Meridiani Publishing House, Tbilisi, 2006;

15. Shalva Kurdadze, Nino Khunashvili, "Georgian Civil Procedure Law", Second Edition, Meridiani Publishing House, Tbilisi, 2015;

16. Simon Chkhaidze, "Absentee Decision in Civil Procedure - Main Problems", Analysis of Judicial Practice, Journal of Justice and Law №4'12 Tbilisi, 2012;

17. Lado Chanturia, "General Part of Civil Law", Samartali Publishing House Tbilisi, 2011;

18. Decision of the Chamber of Civil Cases of the Supreme Court of Georgia of December 27, 2018 in the case №AS-1428-2018;

19. Judgment of the Chamber of Civil Cases of the Supreme Court of Georgia of 17 February 2017 in the case №AS-1063-1023-2016;

20. Judgement of the Chamber of Civil Cases of the Supreme Court of Georgia on January 26, 2016 in the case №AS-493-467-2015;

21. Judgement of the Chamber of Civil Cases of the Supreme Court of Georgia of October 9, 2015 in the case №AS-898-860-2014;

22. Judgment of the Chamber of Civil Cases of the Supreme Court of Georgia of 23 July 2015 in the case №AS-646-612-2015;

23. Judgment of the Chamber of Civil Cases of the Supreme Court of Georgia of 17 April 2015 in the case №AS-58-57-2014; 
24. Judgment of the Chamber of Civil Cases of the Supreme Court of Georgia of January 9, 2015 in the case №AS-307-289-2014;

25. Judgment of the Chamber of Civil Cases of the Supreme Court of Georgia of 9 June 2014 in the case №AS-880-838-2013;

26. Judgment of the Chamber of Civil Cases of the Supreme Court of Georgia of 22 April 2013 in the case №AS-1586-1489-2012;

27. Judgment of the Chamber of Civil Cases of the Supreme Court of Georgia of 25 March 2013 in the case №1350-1275-2012;

28. Judgment of the Chamber of Civil Cases of the Supreme Court of Georgia of 12 January 2012 in the case №AS-1509-1517-2011;

29. Judgement of the Chamber of Civil Cases of the Supreme Court of Georgia of 15 November 2011 in the case №AS-988-1021-2011;

30. Judgment of the Chamber of Civil Cases of the Supreme Court of Georgia of 7 November 2011 in the case №AS-352-335-2011;

31. Judgment of the Chamber of Civil Cases of the Supreme Court of Georgia of 4 April 2011 in the case №AS-71-62-2011;

32. Judgment of the Chamber of Civil Cases of the Supreme Court of Georgia of 19 November 2007 in the case №AS-271-601-07;

33. Judgment of the Chamber of Civil Cases of the Supreme Court of Georgia of 11 July 2007 in the case №AS-322-675-07;

34. Judgment of the Chamber of Civil Cases of the Tbilisi Court of Appeal of 2 December 2014 Judgment in Case №2b / 2737-14;

35. Rainer Burbulla, Parteiberichtigung, Parteiwechsel und Verjährung, Monatsschrift für Deutsches Recht, 61. Jahrgang, Heft 8, 2007;

36. Rudolf Bussert, „Bürgerliches Recht für Betriebswirte“, 2. Aufl., Gabler Verlag, Wiesbaden, 2012;

37. Mitgliedern des Bundesgerichtshofes, „Das Bürgerliche Gesetzbuch: mit besonderer Berücksichtigung der Rechtsprechung des Reichtsgerichts und des Bundesgerichtshofs”, 12. Aufl., Band 1, „de Gruyter“, Berlin, 1982;

38. Silvia Dullinger, „Bürgerliches Recht Schuldrecht Allgemeiner Teil“, Band II, 4. Aufl., SpringerWienNewYork, 2010;

39. Franz Gschnitzer, „Allgemeiner Teil des bürgerlichen Rechts“, Springer-Verlag, Wien, 1966;

40. Jacob Eduard Hasler, „Die Wirkung der Verjährung bei der Schuldklage“, Kessinger Publishing, 1872;

41. Thomas Hoeren, „IT-Recht“, Universität Münster 2016, S. 144 <https://www.itm.nrw/wpcontent/uploads/Skript_IT_Stand_April-2017.pdf>[ Last seen 24.03.2021];

42. Martin Klose, Vindikationsverjährung: Gewogen für verfassungswidrig befunden! Rewiss (RW) Heft 2, 2014;

43. Alfred Koller, Unterbrechung der Verjährung, Schweizerische Juristenzeitung 113 (2017), Nr. 9, 2017;

44. Caroline Meller-Hannich, Die Einrede der Verjährung, in JuristenZeitung, 60. Jahrgeburtstag, №13, 2005;

45. Frand Peters, Der Antrag auf Gewährung von Prozesskostenhilfe und die Hemmung der Verjährung, JR Heft 4/2004, 2004;

46. Markus Philipp, „Verjährungshemmung durch Rechtsverfolgung, Insbesondere ein Beitrag zur Behandlung verfahrensrechtlich fehlerhafter Rechtsverfolgungsmaßnahmen des §204 Abs. 1 BGB“, „Mohr Siebeck“, Tübingen 2018; 
47. Hans-Bernd Schäfer, Ben Fuhrmann, Zivilrechtliche und rechtsökonomische Aspekte zum Dieselskandal der Volkswagen AG, Wirtschaftsdienst, 98. Jahrgang, Heft 4, (243-251), Heidelberg, 2018;

48. Martin Schmidt-Kessel, „Ein einheitliches europäisches Kaufrecht? Eine Analyse des Vorschlags der Kommision“, „De Gruyter“, München, 2012;

49. Lena Rudkowski, „Wirtschaftsrecht: BGB AT, Schuldrecht, Sachenrecht “, „Springer Gabler “, Wiesbaden, 2016;

50. BGH Urt. v. 22/03/2001 - IX ZR 407/98;

51. Oxford Architects Partnership vs Cheltenham Ladies Gollege [2006] APP.L.R 11/17;

52. Ronex Properties vs John Laing Construction [1983] QB 393, 404. 